\title{
The Challenges of Food Security in Nigeria
}

\author{
Saheed Matemilola, Isa Elegbede \\ Brandenburg University of Technology Cottbus-Senftenberg, Brandenburg, Germany \\ Email:matem7_saheed@yahoo.com
}

How to cite this paper: Matemilola, S. and Elegbede, I. (2017) The Challenges of Food Security in Nigeria. Open Access Library Journal, 4: e4185.

https://doi.org/10.4236/oalib.1104185

Received: November 23, 2017

Accepted: December 17, 2017

Published: December 20, 2017

Copyright $\odot 2017$ by authors and Open Access Library Inc.

This work is licensed under the Creative Commons Attribution International License (CC BY 4.0).

http://creativecommons.org/licenses/by/4.0/

\begin{abstract}
Squealing to the discovery of petroleum, Nigeria has rapidly grown into a major food importing nation as the government has become neglectful of the agricultural sector since petroleum is considered a more viable resource for economic development. This situation quickly polarized the nation into high and low income groups. Unfortunately, while only small fraction of the population benefited from the oil wealth, the population suffered the misfortune of food insecurity as they can hardly afford the rising prices of imported foods. However, though at a subsistence level, a sizable ratio of the population in Nigerian is still employed in the Agricultural sector. This paper highlights the important role of agricultural revamping in overturning the food insecurity problems that befell Nigeria and the coping strategies.
\end{abstract}

\section{Subject Areas}

Food Science \& Technology

\section{Keywords}

Undernourishment, Government, Food Security, Agriculture Resource, Rural Areas, Hunger

\section{Introduction}

During the 1996 World Food Summit of November, held in Rome, all heads of Government or their representatives at the summit pledged their support and commitments to achieving global food security and alleviation of hunger with the aim of halving the population of undernourished persons by the year 2015 [1]. Despite this unprecedented effort by international institutions, the population of the undernourished people in the world still constitutes a major problem in most parts of the world. Based on 2015 assessment of the Food and Agriculture Organization of the United Nations (FAO), around 795 million people in 
the world remained undernourished. This figure represents 167 million and 216 million reduction in the last decade and since 1990 respectively [2].

Food security is a phenomenon which is multidimensional with economic, environmental and social aspects. Unfortunately, as can be seen in Table 1 below, the greater share of the population of the undernourished is located in the developing countries. Although the total population of the food insuring people in Asia outweighs that of Africa, 18 out of 23 nations where undernourishment is prevalent are from Africa [3].

Food is no doubt, the most basic of all human survival needs. Although, so many efforts have been sunk in improving the quality as well as production of world food supplies, food insecurity remains prevalent, particularly in the global southern nations of Asia and Africa, and in Nigeria, malnutrition has resulted in death of many of its citizens. African Food Security Briefs (AFSB) estimated that approximately one out of every three persons in the sub-Saharan Africa is undernourished [5]. Achieving a sustainable economic development in Nigeria and Africa at large will continue to be a mirage without well-nourished and healthy people. In fact, failure to ensure food security has unavoidably resulted in many social problems including civil unrest and riots in many major cities of the world. Behnassi et al. [6] described food system and its governance as a process with complex web which many times overlapped or even contradicted with formal policies and regulations, and made even worse by the unwritten laws and practices which may not be susceptible to political subjugations. Food insecurity is therefore strongly linked with other global issues, such as population growth, surge in energy demand as well as completion for land and water and issues of climate change [6].

Though Nigeria prides itself as the giant of Africa with its economy becoming the largest in 2014, the poverty rate in the country is alarming [7]. Not less than $70 \%$ of the Nigerian population is surviving on less than a dollar per day while food insecurity prevalence in the low income urban house-holds and rural areas respectively stands at $79 \%$ and $71 \%$ [5]. Since the discovery of oil in Nigeria in

Table 1. Number of malnourished people (millions) around the world (2000-2016).

\begin{tabular}{lcccc}
\hline & $2000-02$ & $2005-07$ & $2010-12$ & $2014-16$ \\
\hline World & 929.6 & 942.3 & 820.7 & 794.6 \\
Developed regions & 21.2 & 15.4 & 15.7 & 14.7 \\
Developing regions & 908.4 & 926.9 & 805.0 & 779.9 \\
Africa & 210.2 & 213.0 & 218.5 & 232.5 \\
Asia & 636.5 & 665.5 & 546.9 & 511.7 \\
Latin America and the Caribbean & 60.4 & 47.1 & 38.3 & 34.3 \\
Oceania & 1.3 & 1.3 & 1.3 & 1.4 \\
\hline
\end{tabular}

Source: [4]. ${ }^{\star}$ Data for $2014-16$ refer to provisional estimates. 
the 1970s, the agriculture sector became less important to the government as it cannot withstand the economic sagacity of the oil industry. Thus, Nigeria became heavily dependent on importation of food [8]. The rural areas have become even more vulnerable to malnutrition, erratic supply of food items, unaffordable food costs, low quality foods and sometimes complete lack of food. This situation is more prevalent in many parts of the northern region of Nigeria [9].

This paper is intended to review the menace of food insecurity phenomenon in Nigeria while identifying the causative factors and coping strategies that can facilitate food security.

\section{Historical Background}

Nigeria is located in the western part of Africa in the Gulf of Guinea and is situated between Longitudes $2^{\circ} 2^{\prime}$ and $14^{\circ} 30^{\prime}$ east and between Latitudes $4^{\circ}$ and $14^{\circ}$ north. Nigeria is blessed with land mass spanning over an area of $924,000 \mathrm{~km}^{2}$ and is surrounded by the Republic of the Niger to the north, Benin republic to the west, Republic of Chad to the north-east, Cameroon to the east, and the Atlantic Ocean to the south [10]. While the Nigerian population is growing rapidly at an estimated growth rate of $2.8 \%$ per annum, life expectancy stands at 47 years. As reflected in Figure 1, the last collected population data by the Nigeria's National Bureau of Statistics in 2012, revealed a total population of about 166.2 million people. By 2045, it is projected that the population of Nigeria will surpass that of the US and will reach 390 million by 2050. When Nigeria declared independence from England in 1960, the estimated population was only 45.2 million people. That figure represents a growth of about $268 \%$ from the year 1960 to 2012 [11].

Table 2 presents Nigeria's land size and usage. The total area occupied by Nigeria is 92.4 million hectares $\left(924,000 \mathrm{~km}^{2}\right)$ of which land and water respectively encompass 79.4 million and 13.0 million hectares. Agricultural land covers about

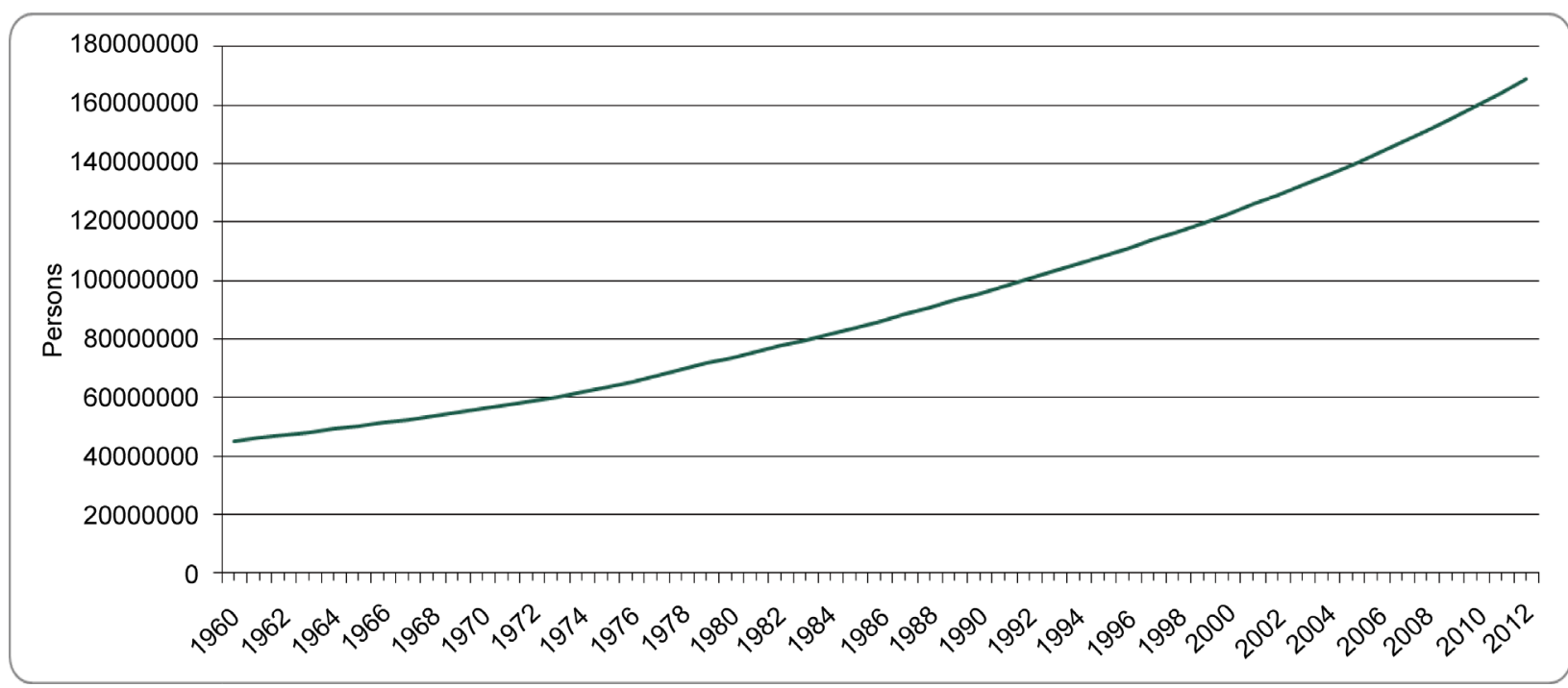

Figure 1. Nigerian population, 1960-2012. Source: [12]. 
Table 2. Land use in Nigeria.

\begin{tabular}{lcc}
\hline \multicolumn{1}{c}{ Land size } & Percentage (\%) & Quantity (million Ha) \\
\hline Total area & 100 & 92.4 \\
Land area & 85.9 & 79.4 \\
Water bodies & 14.1 & 13.0 \\
Land use & & \\
Agricultural land & 77.8 & 71.9 \\
Arable cropland & 30.5 & 28.2 \\
Permanent cropland & 2.7 & 2.5 \\
Pastureland & 30.6 & 28.3 \\
Forest and woodland & 11.6 & 10.9 \\
FADAMA & 2.2 & 2 \\
Other land & 8.1 & 7.5 \\
\hline
\end{tabular}

Source: [15].

$78 \%$ of Nigeria's total land area equivalent to 71.9 million hectares and placing Nigeria on the global map of the top biofuel potential countries. Disappointingly, only about 28.2 million ha of the agricultural land is actually really being cultivated. Still the farming practice in much of the cultivated land is the bush fallow system, such that the land is left idle the soil to naturally regenerate its fertility over a period of time. Also, out of the 2 million ha of land estimated to be irrigable, only $7 \%$ or about 220,000 ha is actually irrigated. This reflects a gross disproportionate utilization of agricultural land when compared to the rate of population growth [13].

Nigeria is blessed with a very diverse and rich vegetation capable of supporting large population of livestock and has estimated surface water volume of about 267.7 billion cubic meter and underground water of about 57.9 billion cubic meters. The ecological zones in Nigeria are also very diverse with the semi-arid Sudan (Sahel) zone, Guinea Savannah and Derived Savannah zone as well as Forest and Mangrove (high rainfall, moist sub-humid and very high humidity) zone. A few variations exist within each ecological zone. The ecology and trends in precipitation in a region determines what kind of farming system the people will practice, their food preference and how they make use of natural resources in their environment [10] [14].

Agriculture, since independence, has been a major contributor to the Nigeria economy. The agriculture sector has been metamorphosed by commercial activities from small to medium and large-scale level of the market. The principal cash crops as shown in Table 3 include cocoa, oil palm and rubber while major staple foods are rice, cassava, yams, maize, taro, sorghum and millet. Production of timber and livestock rearing such as goats, sheep, cattle and poultry as well as artisanal fisheries are the common occupation [16]. Agriculture in Nigeria has remained the largest non-oil contributor to the national economy, accounting 
Table 3. Production data for major agricultural crops in Nigeria, 2010.

\begin{tabular}{ccc}
\hline Agricultural resource & $\begin{array}{c}\text { Production area } \\
\text { (thousand ha) }\end{array}$ & $\begin{array}{c}\text { Total production } \\
\text { (thousand metric tons) }\end{array}$ \\
\hline Cowpea & 2860 & 3368 \\
Cassava & 3482 & 42533 \\
Maize & 4149 & 7677 \\
Cotton & 399 & 602 \\
Soybeans & 291 & 356 \\
Groundnut & 2785 & 3799 \\
Sorghum & 4960 & 7141 \\
Millet & 4364 & 5171 \\
Rice & 2433 & 4473 \\
\hline
\end{tabular}

Adapted from: [19].

for $41.84 \%$ of the GDP in 2009 and employing almost $70 \%$ of the national work force. The farmers are mostly small-scale subsistence farmers totaling about 14 million with an average farm size of 1 hectare in the south and 3 hectares in the north of Nigeria [17]. Despite the fact that the sector has been neglected by the Federal Government sequel to the discovery of commercial quantity of petroleum resource in 19, the inevitability of agriculture to the Nigerian economy cannot be over emphasized [18].

Nigeria is grossly an agrarian state which is reflected in the fact that over 70\% of her economically active population is employed in the agriculture sector [20]. The difference lies in the kind of crop that cultivated in the various regions of the country depending on the soil characteristics and climatic conditions. However, due to the discovery of oil in most of the south-south region of the country, agricultural activities have been grossly limited resulting from the consequential industrialization and frequent oil spillage. Also, agricultural activities in the north are sometimes plagued by extreme weather conditions such as draught and flooding during the raining season. The south-west and south-east have over the years had a relatively balance conditions for agriculture but unfortunately, these two regions also have the highest level of education in the country and mostly seek for opportunities outside the agriculture sector.

\section{Concept of Food Security}

Almost 240 million people, or better put, one out of every four persons in the sub-Saharan Africa, lack access to adequate food. Hike in prices of food items and drought are forcing the population into hunger and starvation. The population of the world has now crossed the 7 billion mark, but how many will there be to feed? [21]. The term "food security" first emerged in the mid-1970s, at the World Food Conference (1974). During the conference food security was defined in terms of supply of food- "assuring the availability and price stability of 
basic foodstuffs at the international and national levep' [22]. Since the World Food Conference of 1974, the concept of food security has evolved into what is now generally agreed the standard definition which was adopted during the World Food Summit in 1996. The World Food Summit, 1996, agreed that food security "exists when all people, at all times, have physical and economic access to sufficient, safe and nutritious food that meets their dietary needs and food preferences for an active and healthy life" [23].

From this definition, four components of food security are identifiable: availability, access, utilization and stability of food. Based on the practical guide of Food Security Information for Action, all four components must be satisfied simultaneously to meet the objectives of food security. Based on FAO [23] and Simon [24] the four components can be delineated as follows:

Availability: There has to be physical, social and economic access to sufficient and nutritious food by all people and at all times. Such food must satisfy the dietary needs and preference of the people. It is the amount of food physically available in a region or place. To a great extent, food availability depends on the level of local production, imports, stock levels and net trade in food items.

Access. This refers to economic, social and physical access to food by all people at all times. That an adequate amount of food is available at the regional, national or international level does not imply it is accessible at household level. It must be locally accessible and affordable.

Utilization: Generally, utilization refers to the pattern in which the body makes use and benefits from the various food nutrients. Utilization id determine by food quality, nutritional values, preparation method and storage as well as feeding pattern.

Stability: this refers to the stability of food availability, accessibility and utilization over time. All three components must be present simultaneously at all times. A person who has adequate access to quality food today is still considered food insecure if he has periodic inadequate access to food which may cause his nutritional level to deteriorate. Variation in weather conditions, political and economic instability, and price fluctuation are some factor that may impact on food security status.

Food security sits on the top of the list of targets of Millennium Development Goals (MDGs). Though, over 60 countries made great success in their effort to meet the MDG hunger target of halving the population of food insecure people between 1990 and 2015, food security has remained one of the greatest challenges in sub-Saharan Africa [21]. Some hunger hot spots have raised special concerns particularly in Africa. Some 39 nations were experiencing grave food shortage and needed food aid from other nations around the world as at 2006. 25 of these highly food insecure countries were from Africa (see Table 4) [22].

\section{Nigeria and the Menace of Food Insecurity}

With over 160 million people, Nigeria is the most populated country in Africa 
Table 4. Global food emergencies, 2005.

\begin{tabular}{cccccc}
\hline Dominant variable & Africa & Asia & Latin America & Europe & Total \\
\hline Human & 10 & 3 & 1 & 1 & 15 \\
Natural & 8 & 7 & 1 & 0 & 16 \\
Combined & 7 & 1 & 0 & 0 & 8 \\
Total & 25 & 11 & 2 & 1 & 39 \\
\hline
\end{tabular}

Source: [22].

and represents about 47 percent of the population of the whole of West Africa. Agriculture is the major occupation in Nigeria, employing almost two-thirds of the active work force and contributing 40 percent of the national GDP [25]. However, based on date from U.S. Energy Information Administration (2015), Nigeria has the largest natural gas reserves in Africa and is the continent's biggest oil exporter. These wealth of resources have helped it maintain Nigeria's relatively steady economic growth even in the face of recent global financial meltdown. Nigeria leapfrogged South Africa as Africa's largest economy in 2013 with Nigeria's GDP growing from $\$ 169.48$ billion in 2010 to 522.64 billion in 2014 (Figure 2 below) [26]. This development cushioned Nigeria's economy to 24th largest in the world, behind Poland and Norway and leap-frogging of Belgium and Taiwan. It also means that Nigeria's GDP per capita substantially rose to $\$ 2689$, up from a previous estimate of $\$ 1555$. Unfortunately, the new figures will not put more money in the pockets of the common man in Nigeria, where about $70 \%$ still live below $\$ 1.25 /$ day [27]. The new figures according to Naisbitt \& Naisbitt [27] only emphasis the level of marginalization in a country in which a generation of multimillionaires and billionaires has emerged.

However, economists both locally and internationally have severally pointed out that Nigeria's economic output is underperforming. Despite the amount of resources the nation sit upon and the rapid economic progress, poverty have remained deeply rooted in the in Nigeria as about 70 percent of the population still live below the poverty line as earlier established. Also, the 2012 Global Hunger Index ranked Nigeria 40th out of 79 nations while the 2011 UNDP Human Development Index placed Nigeria 156th out of 187 countries. The prevalence of poverty and hunger is more pronounced in the rural regions of Nigeria where up to $80 \%$ of the population survive on less than acne US dollar per day [25]. In the rural Nigeria, inadequate post-harvest technology and poor distribution of food have combined with poverty to form an almost insurmountable challenge and especially with unpredictable variations in weather conditions [9].

The International Fund for Agricultural Development (2012), rates Nigeria as the number one producer of yam, cassava and cowpea in the world; yet Nigeria remains a food insecure nation and relies heavily on importation of grains, livestock products, and including fish. As previously opined by Omorogiuwa, et al. (2014), Nigeria has about 75 percent of its land suitable for agriculture, but 
NIGERIA GDP

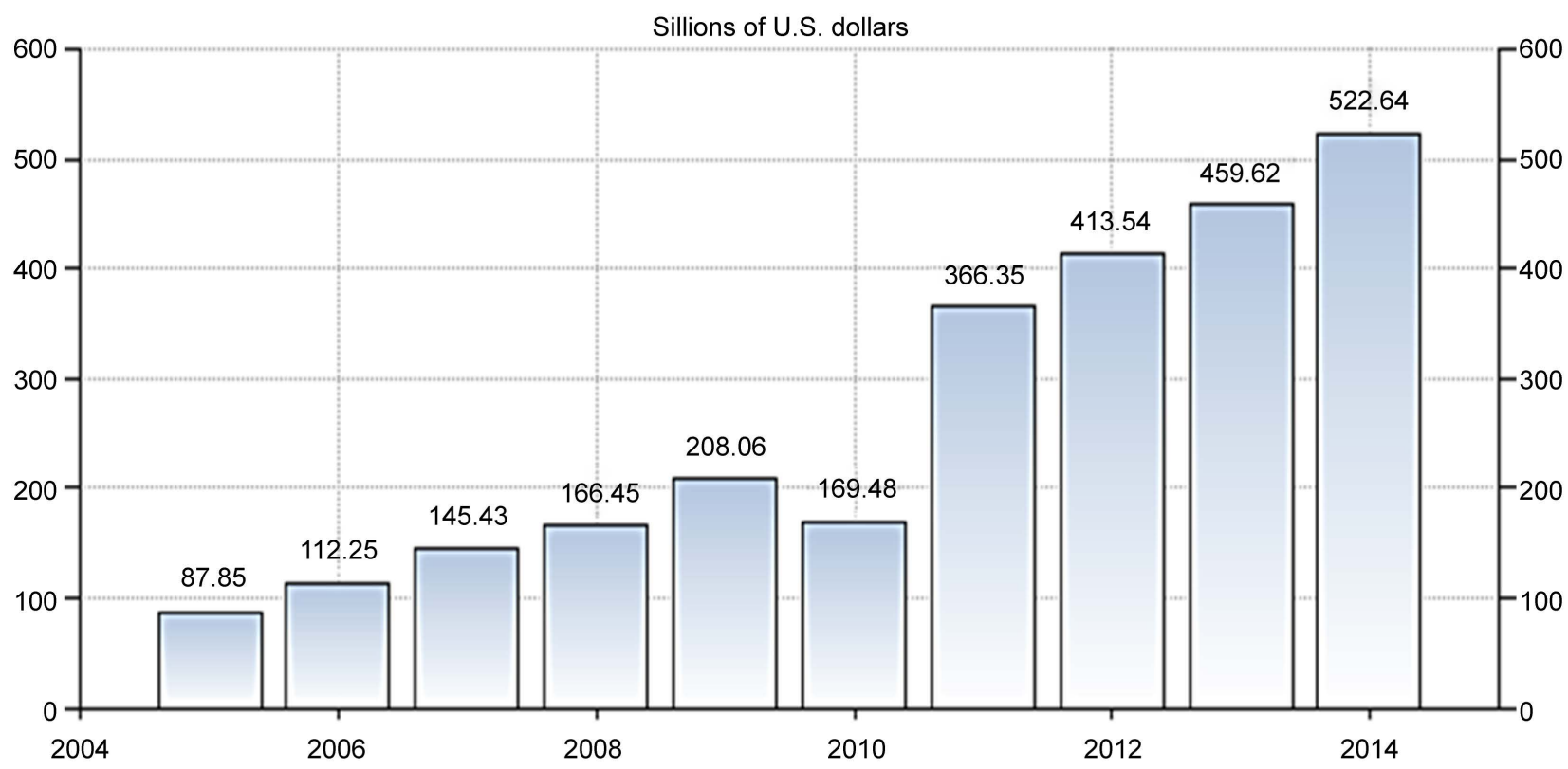

SOURCE: WWW.TRADINGECONOMJCS.COM | WORLD BANK

Figure 2. Growth in Nigeria's GDP 2004-2014 [26].

only 40 percent is actually cultivated. Majority of the rural populace engage on subsistent farming on small plots of land to feed their households and relying on seasonal rainfall. Lack of access to necessary infrastructures such as roads has further worsen the rural poverty situation by disconnecting the rural farmers from required inputs and the markets [28]. But the question is, how did Nigeria get here?

In the 40 s and early 50 s, food insecurity was not a common issue that Nigeria has to contend with. The agricultural system practiced ably sustained the population and have surplus to export. Different regions in Nigeria specialized in different kinds of crop production, whether food or cash crops and there was unity in the diversity. This system strengthens the country's food self-sufficiency. For instance, in the northern Nigeria, groundnut production was a common practice and the region is known for its groundnut pyramids, the western Nigeria is known for cocoa cultivation and it has the cocoa mountains, cultivation of palm plantation is common in the eastern Nigeria and the region is known for its oil palm and kernel heaps while the rubber plantation is the common practice in the mid-west [29].

However, the agriculture sector began a downturn when oil was discovered in 1956. When exportation of petroleum products started in 1958, interest in agriculture begins to dip. The effect of the decline is gradual but steady with rising cost of food items, particularly those of staple foods. For example, the price of rice increased significantly by over 100 per cent since 2006. According to Nigeria's Minister of Agriculture and Water Resources, 2.5 million metric tons of rice 
is required to sustain Nigeria yearly, but only less than half a million metric tons is produced annually. With these figures, it implies that Nigeria has 2 million tons deficit of rice, thus the need to import to meet-up with the annual demand [29] (Figure 3).

\section{Causes of Food Insecurity}

Food insecurity is a multifaceted problem. It is quite an uphill task discussing the driving factors for food insecurity in Nigeria. Nigerians lack enthusiasm for local products and often consider them inferior to imported food products. The emergence of oil sector marked the imminent end of the agriculture sector as the huge revenue generated from the petroleum products shifted attention from agriculture. The government embarked on importation food and local production shrinked away, especially as wealth from oil has changed the status and tastes of many Nigeria in favor of foreign goods [31]. This couple with socio-political instability which precluded the economic downturn, civil war, dwindling human resource base, gender inequality, education decadence, poor health facilities and the general loss of good governance have coexisted to further degenerate food accessibility. The following among others have however, been identified as the prime agents of food insecurity in Nigeria.

\subsection{Insufficient Production}

While Nigeria only has a fixed area of arable land, its growing population will soon stretch land availability to it limits that it will not be able to sustain the population. Also, with increase in number of middle income earners in developing countries, more people can increase their meat consumption (see Figure 4 below). This will increase the competition for land space putting further pressure on grain and soybean prices, supplies and reserve, since production of meats will require far more land space [32].

The major problem here is that the agricultural sector has remained under

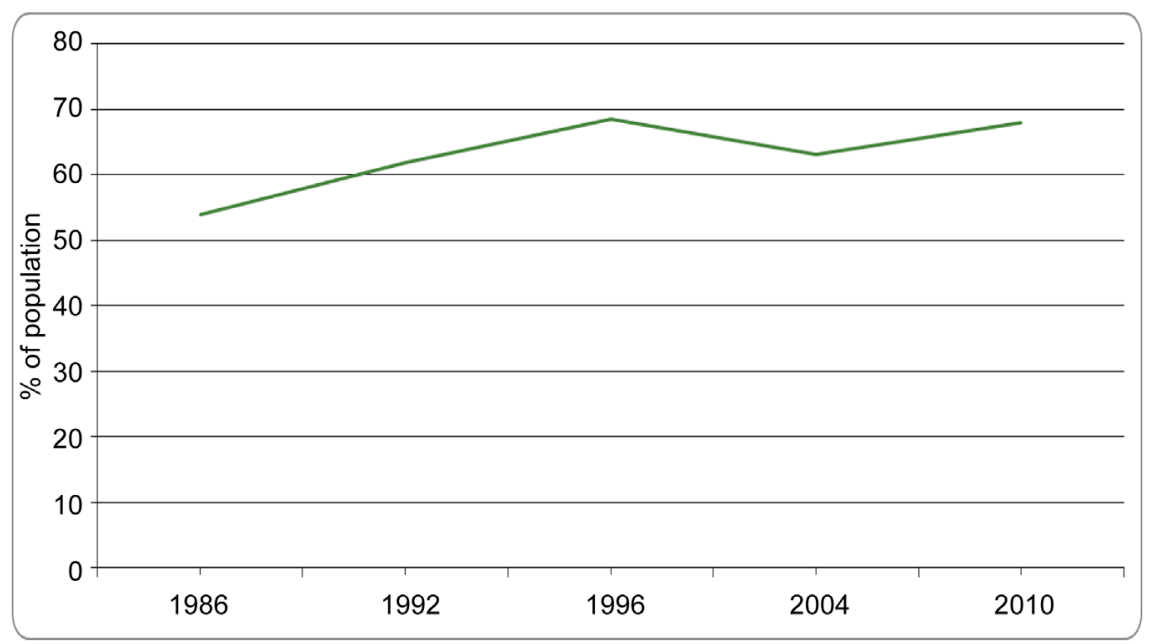

Figure 3. Poverty head count ratio at $\$ 1.25 /$ day (\% of population). Source: [30]. 


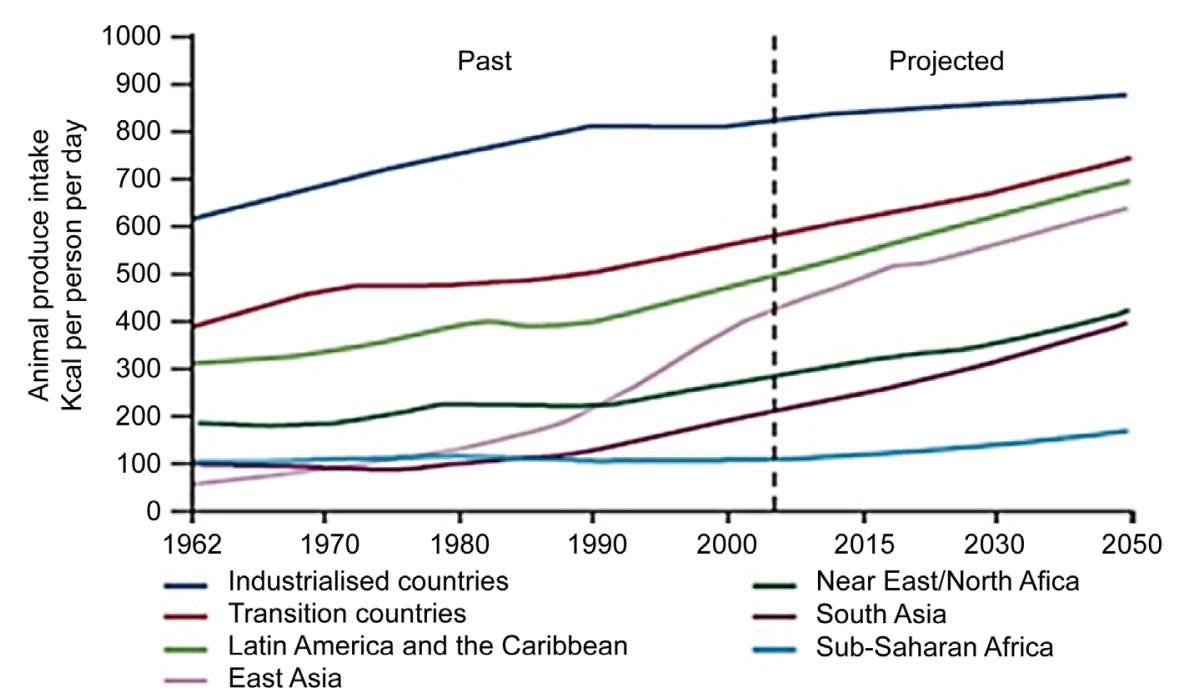

Figure 4. Projected global increase in average animal produce consumption. Source: [32].

developed and depended too much on primary agriculture system with degraded low fertile soils, less external farm inputs utilization and significant loss of food crops both before and after harvest, and lack of facilities for storage and preservation of food all of which have cumulatively contributed to price fluctuation of agricultural products [33]. Furthermore, agriculture is mostly practiced by the farmers who cannot access facilities required for optimum food production. According to the World Bank's statistics, $90 \%$ of agricultural production in Nigeria is the output of inefficient small scale farmers. As a result, such farmers only manage to produce sufficient food to sustain their immediate families. Consequently, poverty persisted in Nigeria which has become a capital for politicians to buy the conscience of the voters during elections by offering them peanuts to buy their votes [8].

\subsection{Gender Inequality}

Gender inequality causes and is also a result of food insecurity. It is estimated that $60 \%$ of global chronically hungry people are women and girls, while $98 \%$ of them are from the global south countries [31]. Women face lots of discrimination both in seeking education and job and face similar fate even at home within the household, yet women are mostly responsible for preparing meals and taking care of the children. They in fact, mostly spend all or a good fraction of their income on feeding and their children's needs [34].

Gender inequality is one of the primary driving forces of food insecurity because this is the most important concern of people who are denied access or unable to engage in labor [31]. The vulnerability of women is most pronounced when assessing the effect of food crisis. They constitute the larger ratio of the poverty ridden population especially in Africa. In many parts of the world, when a woman heads a household, they are often more vulnerable to poverty and hunger than a household headed by a man. Where there is no male income 
earner, negative consequences on overall income are often suffered by the household since women often times lack the ability to command labor within and outside the household. Families headed by widow-are particularly at disadvantaged position [35].

The role of women in ensuring adequate land use, as well as food production, processing, distribution and marketing cannot be over emphasized. Otaha [31] stated that. Unfortunately, women often deprived of access to agricultural assets, inputs and service when compared to men. Analysts, according to Otaha [31], have suggested that if women where to have the similar access as men to productive resources, yield would increase by $20 \%-30 \%$, boosting the total agricultural output by $2.5 \%$ to $4 \%$ in developing countries. This gain in production could have lessened the food insecurity status of most developing nations. If gender inequality is minimized and women are given better access to agricultural facilities, achieving food security will be much easier. It has been established over time by raising women's status, poverty will decline nutrition will be enhanced.

\subsection{Inefficient Policies and Corruption}

Food insecurity has persisted in Nigeria and many developing countries because of inefficient policies especially with respect to agriculture, trade, economics and other adjourning sectors. If governments fail with these policies, hunger will naturally persist or even worsen. Indeed, many countries have failed in their efforts to develop due to failure to properly administer policies and initiatives which has connection to food [32]. This problem arises sometimes when the focus on policies objectives, structures and institutions were designed without adequate consideration of public interest. When policies designs which are not inclusive in structure, tend to disenfranchise the exempted populace [33]. Behnassi and Yaya (2011) related that in the past decades, food security was not a big issue for many countries because if the need ever arise, food could be imported at a relatively cheap price. In this context, production of food locally was not a priority. However, in recent years, food prices have begun to hit the roof making importation more and more expensive, triggering inflation in local food market [32].

Frequent policy changes and poor performance of Nigerian monitoring and implementation agencies also has its toll on food crisis. Each time a new government takes power, the previous food and agricultural policies are abandoned and new ones are set-up. Unfortunately, there are no guarantees that the new ones are better-off, in fact often times they are worse-off. It is only in a bid to create room for financial manipulations. Similarly, the failure of some of the past intervention initiatives like Operation Feed the Nation, Lower River Basin Development Authorities, Green Revolution and regulatory bodies such as the Directorate of Foods, Roads and Rural Infrastructure (DFRRI) and National Agricultural and Land Development Authority (NALDA) have engendered poor agricultural and food productivity in Nigeria [31]. As a result of the successive policy failure, poverty has persisted in Nigeria. Successive governments have 
thus capitalized on this situation created by the previous government to deceive the electorates. Eventually, another wrong leader is voted into power and poor governance succeeds another [8].

Some of the government regulatory/policy problems affecting food security in Nigeria as identified by Okuneye (2009) include:

a. A number of national policies were not helpful in the government effort to transform the agricultural sector e.g. Land Use Act, Importation tariff and other unproductive policies, etc.

b. Habitual alteration/termination of other non-agricultural policies but which may have bearing on agriculture due to changing government regime

c. Inadequate financing of agricultural research and industry as well as farmers capacity building, etc.

d. Unsustainable extension service system

e. Poor planning model and structural framework

f. Unconducive business environment that makes investment in agriculture unattractive to foreign investors

\subsection{Conflicts and Civil Insecurity}

The spread and of civil war and conflict post-independence interrupted production of food and displaced people leaving fertile land uncultivated [8]. Also, there are occasional ethno- religious crisis that has had devastating effects on the Nigerian economic development especially in the area of food production. Other conflicts may take the form of physical fighting, structural violence without declaring war which may result from premeditated pervasion of poverty, rich oppression of the poor, police brutality, intimidation of the common citizens by politicians, women and children oppression and monopolization of resources and power [31].

Civil insecurity born out of the Boko Haram conflict has persisted in the extreme northeast, particularly in Borno, Yobe and Kano states, causing population displacement and limiting crop production below average, restricting market and trade activities and causing higher food prices compared to other areas of the country. Borno and Yobe states have been the focal point of the Boko Haram crisis where farmlands have been converted to battle field and farmer are now banished to camps where they have to depend on aids for survival [36].

According to Nigeria Food Security Outlook, 2012, cereal prices on Maiduguri market in Borno state ranged between NGN 6800 - 7200/100kg (about \$32 $35 / 100 \mathrm{~kg}$ ) in mid-November, 2012. This represents a value 35 percent higher than the five-year average and 12 percent higher than the price in November, 2011 thus, further stretching the food insecurity level in these regions [37].

\subsection{Climate Change and Natural Disasters}

Global changing climate is another important driver of food insecurity that cannot be underestimated. Amongst other impacts, climate change is responsi- 
ble for biodiversity loss in the ecosystem as well as other physical access [8]. Climate change has become one of the key divisor that is redefining the global food equation and thus having so much impact on the food security of particularly developing nations. Behnassi \& Yaya [32] described this climate change phenomenon as a time bomb that is already ticking and waiting to explode. Already we have begun to see the effect on global temperatures, unpredictable weather patterns and physico-biological systems [32].

Although developed nations are largely responsible for emission of greenhouse gas, the impact of the resultant climate change is more severe in developing countries. Climate change impacts on output of agriculture, distribution of agricultural produce accessibility of foods, particularly in the developing parts of the world. People from poor and rural areas are especially vulnerable not just because of their locations but also because of their low adaptive capacity. While advancement in technology has resulted in increases in supply of food in developed countries, the production food crops still rely heavily on climate and weather conditions [32].

Natural disasters and climate variability constitute other key factors making people from less developed nations vulnerable to food insecurity. The impact of such phenomenon as drought, flood and land slide is more pronounced in regions where agriculture highly depends of rainfall [33]. While drought and land slide constitute a major threat for the food availability, excessive rain or flood has had a significant impact on the current hike in food prices. For example, According to Gombe State Emergency Management Agency (GSEMA) statistics, almost 1000 farms within Gombe were destroyed by flood in 2007 alone resulting in loss of tonnes of important local food crops as cassava, yams, maize, sugarcane and vegetable [29]. These events can in fact sometimes cause massive infrastructure destruction loss of stored food leading to inflation of food prices [33].

Nigeria Food Security Outlook of Famine Early Warning Systems Network (2013) reported that Nigeria witnessed an unprecedented flooding case between July and October, 2012 as a result of persistent heavy rainfall couple with the release of water from several dams. This incidence causes the displacement of about 2.8 million people were displaced several months following, the affected households could still not fully recover their livelihoods. High level of food insecurity soon ensued in the regions due to low food stocks and high food prices. However, most households have started returning to their homes to rebuild their livelihoods [36].

\subsection{Low Technology for Processing and Storage}

The use of modern technologies in the production and distribution of agricultural products is very low in Nigeria so the sector depended more on manual labour for farm activities. This is because of lack of innovation in local technology, particularly as it relate to mechanization of agriculture to improve productivity. 
Additionally, local farmers can hardly afford imported technologies and lack maintenance capacity [38]. Inadequate or lack of facilities to preserve food items such as cereals, yam, beans, etc. can result in wastage thereby further deepening the insecurity level of food. Also, lack of food processing apparatus sometime leave farmers with no choice than to consume significant fraction of their harvest within short period. Food processing is an important aspect of agriculture that prevents wastage of food items that cannot be easily stored in their original form by transforming them into other form that can enable their preservation. For an instance, mangos, citrus and pineapple can easily be preserved when converted into fruit juice. To achieve a sustainable food security, effort must be made to avert any wastage [33].

Modern agriculture has become so highly industrialized and dependent on energy. Mechanized farmers are very reliant on consistent power supply which has eluded us has become a mirage for successive government to achieve. Now, much of the agricultural products we consume are produced in farms located far away and processed other distant location before being imported via air, water or land. The whole of these processes requires a lot of power and fuel to keep food price low and affordable for the common man [32]. However, with escalating prices of petroleum products, there have been calls for diversification to increased energy efficiency. One key alternative is biofuel and other agriculture-based energy production. This alternative will create more completion for food item particularly in developing nation and depending on how the process is managed mat increase food insecurity [32].

\section{Nigerian Food Security Policy Review}

The Nigerian government has come up with various strategies to improve the situation. Efforts are now been made to restore agriculture back to its original status before the oil boom and stamping out food insecurity [29]. Several policies and initiatives are now being developed with the aim of providing efficient framework to address food insecurity and malnutrition in Nigeria [9]. In the early 70s, during the military regime, Gen. Yakubu Gowon government out of desperation embarked on a gargantuan importation of rice to alleviate hunger. Unfortunately, the Nigerian ports did not have sufficient facilities to manage such elaborate importation project that later came to be known as the Rice Amada. The ports became choked with rice so much that a committee had to be set up to enable the decongestion of the Port. Despite this effort by the government, the massive amount of imported rice could not solve the long term food insecurity challenges; rather, a comprehensive and inclusive agricultural policy was needed [29].

Jerome (2012), conceive that a review of the period before the Structural Adjustment Program (SAP) era which was introduced in 1986 showed that much of government attention was focus on policies related to industrialization than agricultural primarily because of the discovery of oil. This claim was obvious in 
the First National Development Plan (1962-1968) that strongly emphasized industrialization and the need to exploit abundant resources of the nation. On the contrary however, the Second National Development Plan (1970-1974) attempted to revive the rapidly dwindling food production which was catalyzed by the Nigerian civil war leading to tremendous starvation as a result of food shortages. Shimada (1999) however, faulted this, stating that government only pretend to be rescuing the agriculture since it had shrinked the budgetary spending on agriculture and food security to $7.7 \%$ compared to the $23.1 \%$ allocation to transport sector. Murio [39] also reiterated that the Nigerian government had chosen to depend on the importation of agricultural product particularly food items rather than reviving and building the national capacity on agricultural production.

There was also the National Accelerated Food Production Project (NAFPP) that was inaugurated in 1974 with the objective of boosting the availability of agricultural inputs as well as educating the farmers. Okuneye [40], however availed that, the NAFPP could not achieve its objectives due to ill planning and poor timing in providing farmers with the required extension services. To make up for the failure of NAFPP, the government established the Agricultural Development Program (ADP) in 1975. Under the ADP project, 470 agro service centers where set-up all over the four geo-political zones to avert the difficulty of untimely delivery of extension services to the farmers which was the major undoing of the NAFPP. The ADP was a successful project and was penetrating the rural areas. While ADP was still running, other agricultural and food security projects such as Operation Feed the Nation (OFN) in 1976 and the Green Revolution in 1980, were initiated and ran simultaneously to complement the ADP. These initiatives were captured in the Nigeria's third nation Development plan (1975-1980). These initiatives were part of the government's effort to establish a public-private partnership in food production to ensure an inclusive and self-sustaining agricultural system that limits the country's dependence on importation. The initiatives advocate policy shift that will enable government subsidies and various other incentives for farmer to improve local production of food. The Fourth National Development Plan (1981-1985) took a cue from the third National development plan. Thus, it sought to further improve food productivity and strengthen self-sufficiency. To achieve these objectives, the initiatives worked with other government institutions like the Ministry of Agriculture and Water Resources, Ministry of Labor, Ministry of Commerce, the River Basin and Rural Development Authority (RBRDA) and ADP [41].

In a nutshell, despite the comprehensiveness of the numerous programs and projects, effective implementation could hardly be achieved due to poor governance and corruption. Only until the re-emergence of the civilian administration in 1999 that the much needed attention was given to the agriculture sector and food production. The government thus, restated its commitment to face-out hunger and malnutrition through ensuring adequate food supply. To achieve 
this according to Ojo \& Adebayo (2012), the government initiated a number of food security initiatives, which include:

i. Special Program for Food Security (SPFS):

SPFS is an initiative through which the Nigerian government seek the support of the Food and Agriculture Organization (FAO). The program is aimed at delivering information on new accessible agricultural technologies that has been tested to 109 farming communities scattered across Nigeria's four geo-political zones to improve food production and accessibility as well as to significantly increase the farmer's returns from harvest.

ii. Root and Tuber Expansion Program:

This agricultural program is funded by the International Fund for Agricultural Development (IFAD). The initiative helps to build farmer's capacity on latest technologies for processing tuber and root products and expansion technique particularly for cassava products.

iii. Fadama Development Project:

With funds from various international organizations, the Fadama project was established by the Nigerian government to enable farmers carry on their farming activities all through the year and enjoying an all-season farming. Activities of the program include development of infrastructure, large-scale irrigation, improving farmer's capacity, and creating environmental awareness.

iv. Community-based agricultural and rural development schemes:

This includes various development schemes and programs like "farm settlement" and "back-to-land" schemes. Such schemes are developed to encouraged the public participate more in farming through making farming implement more easily accessible and providing them with various incentives.

v. Provision of infrastructures:

The government embarked on infrastructural projects such as building new link-up roads in the rural areas and carrying out maintenance of existing ones, electrification of the rural settlements, supplying farmers with necessary farm inputs as fertilizer, seedlings and equipment; leasing farm machineries like harvesters and tractors as well as storage facilities to farmers or outright sale to farmers that can afford them to facilitate mechanized farming practice and reduce post-harvest loss.

vi. International Centre for Soil Fertility and Agricultural Development (ICSFAD):

Nigerian government also inaugurated the International Centre for Soil Fertility and Agricultural Development (ICSFAD) in conjunction with the United States. The objective here is to study the factor affecting increased agricultural production in the Nigeria. The Centre will carry out assessment of soil of various types from different Nigerian locations with the aim of determining the type of fertilizer that will be appropriate for farmers on each soil type.

vii. Policy instrument

This refers to the policy instrument and direction through which the govern- 
ment carries out activities such as

a. Banning the importation of some agricultural products which the county can locally produce at sufficient volume. This ban has tremendously help to boost the livestock production and agriculture.

b. Making fertilizer available to farmers at a subsidized rate

c. Improving financing of the agriculture sector through provision of additional funds for state-owned agricultural banks to enable them grant more soft-loans to farmers, and encouraging the conventional banks to grant low-interest loans to all classes of farmers.

\section{Strategies for Achieving Food Security in Nigeria}

Going by its definition, food security however will not be achieved by simply increasing the production of food. Even when food is sufficiently available, a poor hungry man will remain food insecure as long as he cannot afford to buy it [3]. Hence, all four components viz.; availability, accessibility, utilization and stability must be present. Efforts to combat food insecurity will therefore, not only make food available but also ensure that that people can consistently afford to make it ready for consumption. Omorogiuwa, et al. (2014) in "The role of agriculture in the economic development of Nigeria" stated that Nigeria is blessed with abundant fertile agricultural land and favorable climate as well as enviable human resources.

How then can food security be objectives be met in Nigeria? The panacea lies in improving agricultural productivity; enhancing science and technology; building farmers capacity; facilitating access to the market; and good governance amongst others [33]. In this case, the strategies for achieving food security are categorized into economic, social, environmental and technological strategies.

\subsection{Economic Strategies}

a. Promoting decent employment in the agriculture sector: this is particularly effective in the rural areas. A great proportion of the rural population depends on agriculture for survival, yet they are the most food-insecure part of Nigeria. Like in other developing nations of the world, rural farmers in Nigeria are highly informal with casual approach to farming activities. This makes them highly vulnerable to exploitation. Policies and programmes should be implemented to facilitate equitable market place for the informal farmers such as training and monitoring schemes.

b. Promoting the non-farm economy in the rural areas: again the rural population who are most susceptible to food insecurity are the targets here because the Nigerian urban economy is mostly non-farm based. As important as agriculture is to the rural people, there is need for diversification. While some rural farmers may begin to enjoy the dividends of access to the transforming equitable agricultural market enabling them to find their rout out of poverty and food insecurity, others may not be so successful. The whole rural economy cannot be 
based on agriculture. Some may need to exploit other non-farm opportunities which may as well be economically viable such as paid employment or trading. The government needs to provide orientation program and the enable environment for diversification of rural economies.

c. Provision of credit and incentives: according to Oni, et al. (2009), access to credit facilities has been shown empirically in various studies to have improved farmer's productivity. It is important for small-holder farmers to have access to credit facilities particularly during the sowing period to enable them to enable them afford quality seeds, pesticides, fertilizers as well as hire/purchase of equipment needed for production. Fund may also be needed for labor support during harvest and for storage facilities [42]. Other incentives such as subsidy on fertilizers can also help improve farmers' productivity

\subsection{Social Strategies}

a. Social networking and organized farmers cooperation: this is another important factor identified in Oni, et al. (2009) that can significantly improve the livelihood of small-holder farmers through inter-connecting and cooperating with one another. This helps protect the interest of the most vulnerable farmers in a group and can serve as base for human resource development enabling the weaker farmers cope with risks [4]. It can serve as a viable capacity building platform for farmers and other social groups to form a force and gain access to credit facilities, inputs, markets and other resources [42].

b. Accessible education: this is indeed a mechanism that facilitates productivity in any field of career [43]. Lack of or inadequate education is the bane of farmers in Nigeria particularly in the rural settlement. This is mostly not because of their lack of interest but because they lack access to it. The government needs to make education affordable for the low-income urban and rural people. This will improve their ability to navigate opportunities and technical know-how in employing farm implements.

c. Provision of infrastructure: even in the most developed urban centers, lack of basic infrastructures as access roads, electricity and portable water can have immense impact on the economy. For farmers to be productive these basic amenities need to be accessible. Electricity for an instance cannot be compromised to power storage facilities of sometime farm equipments. Road and transport give them access to the market and thus improving their economy.

\subsection{Environmental Strategies}

a. Improved management of industrial effluents: Islam, et al. (2006) in their research of Impacts of industrial effluents on plant and soil in Bangladesh showed that industrial effluents significantly reduce deplete the nutrient content of soil which reduces the growth, yield, and nutrition of agricultural products. In Nigeria, oil spillage, gas flaring and other industrial effluents have consistently constituted a scourge for the agricultural sector, crippling productivity. There is 
a need for an improved monitoring system of industrial compliance to Environmental Management Plan (EMP) and follow-up program to reduce impact on agricultural productivity.

b. Regulation of the use of fertilizers and other agro-chemicals: the importance of fertilizers and agrochemicals in today's agricultural practice cannot be overemphasized. However, they also have their associated environmental consequences. Where nitrogen from fertilizers washes into water bodies it causes eutrophication killing aquatic lives. Phosphorus can also make algae to accumulate in water bodies depriving fishes of oxygen leading to suffocation and thereby affecting the supply or availability of fish for consumption [44] [45]. Measures should be taken to control the usage of fertilizers and pesticides by farmers through trainings and orientation programs.

\subsection{Technological Strategies}

a. Crop rotation and diversification: crop rotation, mixing and diversification is an important practice that can improve quality and yield of agricultural produce [43]. This technique basically help improves soil nutrients and can be used to control pests and diseases. This system should be encouraged amongst farmers.

b. Irrigation system: Oni, et al. (2009) also observed that irrigated farms in the dry savanna agro-ecological zones give higher productivity than non-irrigated farms in the same region. This system will be particularly useful in most part of the northern Nigeria.

c. Promotion of mechanized farming system: Ojo \& Adebayo (2012) noted that the despite the use of indigenous CRP rotation system in Africa, Asia and the Latin Americas, food insecurity has been on the rise as these techniques are not enough to meet the demand of the fast growing populations. There is the need for mechanization of agriculture in Nigeria to improve production through the use of equipments, machineries and implements. Although, some large scale farmers have been using the mechanised farming system, there is the need to promote mechanized farming amongst small-holder farmers. To achieve an overall inclusive agricultural mechanization, the Nigerian government needs to engage other public and private corporations as well as financing institutions [46].

d. Agricultural biotechnology: although agricultural biotechnology which involves genetically modified foods is still not generally accepted due to unresolved safety issues. It represents one of the success stories of science and technology in recent times which has an immense potential to significantly reducing the global food security challenges [29].

\section{Conclusions}

Although food insecurity is a global phenomenon, it is more prevalent in the developing nations including Nigeria. Fortunately, Nigeria is blessed with abun- 
dant fertile land for agriculture and enormous human resource. Nigeria has a rich history of agricultural practice but it all soon changes with the discovery of oil in the now unenviable oil-rich Niger-delta region of the nation. The prospect of huge financial resource that could be generated from the oil resource distracted the nation from its agricultural blessing as all attention was diverted. The so-called financial returns from the oil resources are consistently manipulated and diverted by government officials and alas it is the common man who suffers the consequences. Hunger, starvation and malnutrition are ravaging the nation.

Food security can, however, still be restored in the country but some factors are still militating against the restoration such as insufficient production, gender inequality, inefficient policies and corruption, conflicts and civil insecurity, climate change and natural disasters, low technology for processing and storage amongst others. To surmount this challenges, the government must go back to the drawing board to provide enabling environment through promoting decent employment in the agricultural sector and non-farm sectors as well as providing credit facilities to serve as platform for the most vulnerable to cope with the economic realities particularly in the rural areas. While social networking and cooperation among small holder farmers will give them a voice, the government needs to provide basic infrastructures such as access road and electricity and make education more accessible to build farmers capacity. Oil spillage and other industrial effluents constitute a major source of pollution of soil and water and other components of the environment, thereby reducing agricultural productivity. There is the need for government to develop a robust monitoring mechanism to control indiscriminate discharge of effluent. Lastly, modern science and technologies must be adopted to improve agricultural productivity.

\section{References}

[1] FAO (1996) Rome Declaration on World Food Security and World Food Summit Plan of Action. http://www.fao.org/docrep/003/w3613e/w3613e00.HTM

[2] FAO (2015) The State of Food Insecurity in the World 2015. Meeting the 2015 International Hunger Targets: Taking Stock of Uneven Progress, FAO in Conjunction with IFAD and WFP, Rome.

[3] Ogbonna, J.C., Nomura, N. and Aoyagi, H. (2013) Bioenergy Production and Food Security in Africa. Academic Journals, 12, 7147-7157.

[4] FAO, WFP, IFAD (2012) The State of Food Insecurity in the World 2012. Economic Growth Is Necessary But Not Sufficient to Accelerate Reduction of Hunger and Malnutrition. FAO, Rome.

[5] Akerele, D., Momoh, S., Aromolaran, A.B., Oguntona, C.R.B. and Shittu, A.M. (2013) Food Insecurity and Coping Strategies in South-West Nigeria. Springer Science + Business Media Dordrecht and International Society for Plant Pathology, 407-414.

[6] Behnassi, M., Pollmann, O. and Kissinger, G. (2013) Sustainable Food Security in the Era of Local and Global Environmental Change. Springer Dordrecht Heidelberg, New York. https://doi.org/10.1007/978-94-007-6719-5

[7] Omorogiuwa, O., Zivkovic, J. and Ademoh, F. (2014) The Role of Agriculture in the 
Economic Development of Nigeria. European Scientific Journal, 10, 113-147.

[8] Adeagbo, M.O. (2012) Curbing the Menace of Food Insecurity in Nigeria's Democratic Setting. International Journal of Economic Development Research and Investment, 101-109.

[9] Akinyele, I.O. (2009) Ensuring Food and Nutrition Security in Rural Nigeria: An Assessment of the Challenges, Information Needs, and Analytical Capacity. International Food Policy Research Institute (IFPRI), Abuja.

[10] Azih, I. (2008) A Background Analysis of the Nigerian Agricultural Sector. Oxfam Novib Economic Justice Campaign in Agriculture, Lagos.

[11] World Population Review (2014) World Population Review. http://worldpopulationreview.com/countries/nigeria-population/

[12] Knoema (2014) World Development Indicators (WDI). https://knoema.com/WBWDIGDF2017Sep/world-development-indicators-wdi

[13] Dankumo, A., Riti, J.S. and Ayeni, B.S. (2015) Contribution of Agricultural and Industrial Sectors to the Development of Nigerian Economy from 1995 to 2012. International Journal of Business, Management and Allied Science, 2, 2128-2135.

[14] Aregheore, E. (2011) Country Pasture/Forage Resource Profile: Nigeria. Food and Agriculture Organization of the United Nations.

[15] Ezeanyanaso, C.S., Bugaje, I.M. and Okunola, O.J. (2013) A Sustainable Process for the Synergy between Petroleum and Biofuels Industries in Nigeria. Journal of Sustainable Development in Africa, 15, 1-10.

[16] Offu, A.K.S. (2013) The Nigerian Dependent Management \& Leadership Development in the Post World War II Colonial Nigeria. AuthorHouse, Bloomington.

[17] Corporate Nigeria (2011) The Business, Trade and Investment Guide 2010/2011. Corporate Guide International Publications, New York.

[18] Adene, D.F. and Oguntade, A.E. (2006) The Structure and the Importance of the Commercial and Village Based Poultry Industry in Nigeria. FAO, Rome.

[19] Simonyan, K.J. and Fasina, O. (2013) Biomass Resources and Bioenergy Potentials in Nigeria. African Journal of Agricultural Research, 8, 4975-4989.

[20] Muhammad-Lawal, A., Salau, S.A. and Olawusi, C.O. (2015) Sorghum Storage and Pest Control among Farming Households in Kwara State, Nigeria. Tropical Agricultural Research \& Extension, 18, 68-75. https://doi.org/10.4038/tare.v18i2.5326

[21] Bremner, J. (2012) Population and Food Security: Africs's Challenges. The Population Reference Bureau, Washington DC.

[22] FAO (2006) Food Security. FAO's Agriculture and Development Economics Division (ESA) with Support from the FAO Netherlands Partnership, Amsterdam.

[23] FAO (2008) An Introduction to the Basic Concepts of Food Security. In: Food Security Information for Action: Practical Guides, EC-FAO Food Security Programme.

[24] Simon, G.-A. (2012) Food Security: Definition, Four Dimensions, History. FAO, Rome.

[25] Food Security Portal (2014) Food Security Portal-Nigeria. http://www.foodsecurityportal.org/nigeria

[26] Trading Economics (2014) Trading Economics/Nigeria. http://www.tradingeconomics.com/nigeria/gdp

[27] Naisbitt, J. and Naisbitt, D. (2016) Global Game Change: How the Global Southern Belt Will Reshape Our World. Sage Publications, New Delhi. 
[28] IFAD (2012) International Fund for Agricultural Development (IFAD). Annual Report. IFAD, Monte Forte.

[29] Ojo, E.O. and Adebayo, P.F. (2012) Food Security in Nigeria: An Overview. European Journal of Sustainable Development, 1, 199-222.

[30] Knoema (2012) Poverty and Inequality Statistics. https://knoema.com/WBPS2013Dec/poverty-and-inequality-statistics-december-20 12 ? country $=1000800-$ kosovo

[31] Otaha, I.J. (2013) Food Insecurity in Nigeria: Way Forward. An International Multidisciplinary Journal, 7, 26-35.

[32] Behnassi, M., Draggan, S. and Yaya, S. (2011) Global Food Insecurity: Rethinking Agricultural and Rural Development Paradigm and Policy. In: Food Crisis Mitigation: The Need for an Enhanced Global Food Governance, Springer Science + Business Media, New York, 91-125.

[33] Ilaboya, I., Atikpo, E., Omofuma, F., Asekhame, F. and Umukoro, L. (2012) Causes, Effects and Way forward to Food Insecurity. Iranica Journal of Energy \& Environment, 3, 180-188.

[34] WFP (2009) World Food Program Policy Report. WFP, Rome.

[35] ADB (2013) Gender Equality and Food Security-Women's Empowerment as a Tool against Hunger. Asian Development Bank, Mandaluyong.

[36] FEWS NET (2013) Nigeria Food Security Outlook. FEWS NET, Bauja.

[37] FEWS NET (2012) Nigeria Food Security Outlook Update. Famine Early Warning Systems Network, Abuja.

[38] Nwajiuba, C. (2013) Nigeria's Agriculture and Food Security Challenges. Agriculture \& Food Security, 45-53.

[39] Yoshida, M. (1989) Economic Crisis and Development Policies in African States in 1980s. Institute of Development Economics, Tokyo.

[40] Okuneye, P. (1992) The Problem of Declining Food Production. In: Olanrewaju, S. and Folola, T., Eds., Rural Development Problems in Nigeria, Avebury, Aldershort.

[41] Jerome, A. (2012) Nigeria's Food Security Programs: Implications for MDG’s Goal of Extreme Hunger Eradication. International Journal of Business and Social Science, 3, 243-253.

[42] Reddy, C.R., Rao, P.P., Alur, A.S., Reddy, A.R., Birajdhar, S., Kumar, A.A., Reddy, B.V. and Gowda, C. (2010) Linking Small-Scale Farmers to Credit Institutions. LEISA INDIA, Andhra Pradesh.

[43] Oni, O., Nkonya, E., Pender, J., Phillips, D. and Kato, E. (2009) Trends and Drivers of Agricultural Productivity in Nigeria. International Food Policy Research Institute (IFPRI), Abuja.

[44] Elliott, K.G. (2015) The Effects of Fertilizers \& Pesticides. http://www.livestrong.com/article/139831-the-effects-fertilizers-pesticides/

[45] Engel, H. (2014) Negative \& Positive Effects of Pesticides \& Fertilizer. http://homeguides.sfgate.com/negative-positive-effects-pesticides-fertilizer-38216.h $\underline{\mathrm{tml}}$

[46] CEMA (2014) Advancing Agricultural Mechanization (AM) to Promote Farming \& Rural Development in Africa. CEMA (European Agricultural Machinery). 